\title{
Cultural Differences Identification and its Effect on E-Service Quality Perception
}

\author{
${ }^{1}$ Mohammad Al-Nasser, \\ ${ }^{1}$ Rushami Zien Yusoff, ${ }^{2}$ Rabiul Islam and ${ }^{1}$ Abdullah ALNasser \\ ${ }^{1}$ School of Business Management, \\ ${ }^{2}$ School of Economics, Finance and Banking, \\ College of Business, University Utara Malaysia, Malaysia
}

Received 2013-12-12; Revised 2013-12-29; Accepted 2013-12-30

\begin{abstract}
Cultural differences are one of many forces influencing consumer decision making and the effect of cultural differences on the development and use of information and communication technologies. As different companies are not taking their business outside geographic boundaries, the global activities are opened to a large degree via current communication and information technologies. The aim of the study is to determine the cultural differences identification and its effect on E-service quality perception. A quantitative research design was adopted to collect data. Multiple regression analysis method was used to conduct this study. The findings of the study will contribute to both theory and practice. The results of this study have important contributions and implications for practitioners and policy-makers. This study contributed to the field of service quality expectations relationship with online shopping in the context of developing countries. It also examined the impact of culture on the service quality consumer expectations.
\end{abstract}

Keywords: Cultural Identification, E-Service Quality, Online Shopping, Quality Perception

\section{INTRODUCTION}

In the past decade, a notable significant interest has been shown in the effect of cultural differences on the development and use of information and communication technologies. As different companies are not taking their business outside geographic boundaries, the global activities are opened to a large degree via current communication and information technologies. It is therefore important to understand the impact of cultural differences on the activities (Tractinsky and Jarvenpaa, 1995).

Crotts and Erdmann (2000) found that national cultural differences are one of many forces influencing consumer decision making. Jarvenpaa et al. (1999) found that culture plays a vital role in international marketing as it impacts motives, attitudes, intentions and purchases of consumers. If people hailing from varying cultures view Internet trustworthiness in varying levels, it is Corresponding Author: Mohammad Al-Nasser, School of Business Management, College of Business, University Utara Malaysia, Malaysia necessary to understand the impacts of culture on the perceptions of consumers in order to establish how they develop their perception of Internet shopping.

An understanding of what culture is, its dimensions, definitions and conceptualizations are important for research on culture (Straub et al., 2002). Kroeber and Kluckhohn (1978) defined culture as "patterns, explicit and implicit, of and for behavior acquired and transmitted by symbols, constituting the distinctive achievements of human groups, including their embodiments in artifacts. Leung et al. (2005) defined culture as "values, beliefs, norms and behavioral patterns of a group-people in a society for national culture, staff of an organization for organizational culture, specific profession for professional culture.

Cultural dimensions are value constructs or psychological dimensions that can be used in describing an exact culture. Culture has many dimensions and many authors have provided different

AJEBA 
dimensions based on the different definitions of culture. Hofstede (1991) conducted the most comprehensive cross-cultural study to date in which he developed five cultural dimensions. This cultural dimension shows one of the important frameworks to understand the effect of culture on consumer behavior literature.

Park and Jun (2003) investigated the relationship between culture and differences in the behavior of online buying. They carried out a cross-cultural comparison of on-line purchasing behaviors and examined the impacts of using Internet, perceived risks and innovation on a cross-cultural basis. In their study, they compared the factors affecting online buying behavior of Koreans and Americans. They demonstrated significant differences in Internet usage and the perceived risks of online shopping between the two cultures.

Vijayasarathy (2002) According to there exist four types of salient beliefs that can collectively be used to highlight a person's attitude toward e-shopping, namely, product perception, shopping experience, customer service and consumer risk. Theory of Reasoned Action was adapted in the study conducted by Cho (2004) Verhoef and Langerak (2001) in an attempt to examine e-shopping behavior. Specifically, Cho (2004) contended that attitude toward e-shopping can be shown through the following factors: Perceived outcome of e-shopping, previous behavior and attitude toward channels of shopping. The possibility of backing down of any online transaction planned is determined through the aggregate dimensions coupled with the attitude toward e-shopping. On the other hand, Verhoef and Langerak (2001) considered the innovation diffusion theory constructs and hypothesized that an individual's intention to e-shopping is reflected through his/her perceptions of the following: The relative advantage of e-shopping and e-shopping compatibility and complexity. In these studies, subjective norms were not included as determinants of behavioral intention (Fishbein and Ajzen, 1975).

Theory of Reasoned Action (TRA) proposed by Ajzen and Fishbein (1980) is a commonly employed theory in marketing studies. It advocates that a person's behavior is reflected through his/her intentions, which can be predicted from his/her attitudes concerning the behavior and subjective norms. Based on the line of predictions, the attitudes of an individual may be predicted through his/her beliefs concerning the outcome of the behavior. Theory of Reasoned Action
(Fig. 1) is a broad theory and it does not pinpoint particular beliefs that may be important in specific situations. It is utilized for the prediction of different behaviors including finance, marketing, health. Therefore, Theory of Resound Action is suitable to be used in the context of online shopping studies via a specific web vendor. Based on the discussion above, researcher used Theory of Reasoned Action as a base theory for the present study.

A framework refers to a conceptual model of the way the relationships among several factors, identified as important to the issue, are theorized (Sekaran, 2003). The present study develops a conceptual study based on a thorough review of literature, as indicated in the Fig. 2. The research model suggests that consumers' decisions to shop via the Internet are affected by their perception of quality of e-service. Additionally, the conceptual framework suggests perceived trust as a mediating variable, to show how e-service quality can increase consumers' trust while risk works as a moderator that affects this relation. Finally, the dependent variable is attitude towards online shopping. The researcher included culture construct into the conceptual framework as an antecedent variable to prove that consumers' perceptions of e-service quality are influenced by various cultures. The researcher came up with a combination of various variables from many studies to develop the modified conceptual framework, which would be studied and analyzed.

According to social exchange theory (Blau, 1964), trust is developed only when the trustee's manner is acceptable and in line with the trustor's expectations. In addition, empirical findings revealed that trust increased with the increase in the customer's attitude to buy a product from the firm (Jarvenpaa et al., 2000). Based on Grabner-Krauter and Kaluscha (2003) study, lack of trust was the reason that prevented online shopping. Hence, the establishment of trust in online shopping is considered among the primary factors that enable successful online businesses.

In the present study, all the above issues are addressed. Moreover, none of the studies conducted tests on the mediating role of trust and the moderating role of risk in the e-service quality-attitude towards eshopping relationship. The only study to test the mediating role of trust but confined to antecedent factors (i.e., user and website characteristics) was conducted by Sultan et al. (2005). 


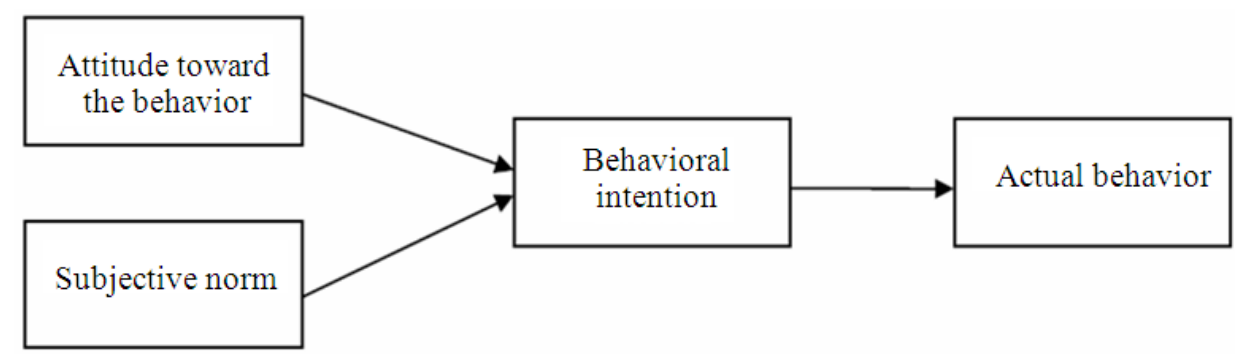

Fig. 1. Theory of reasoned action source (Davis et al., 1989)

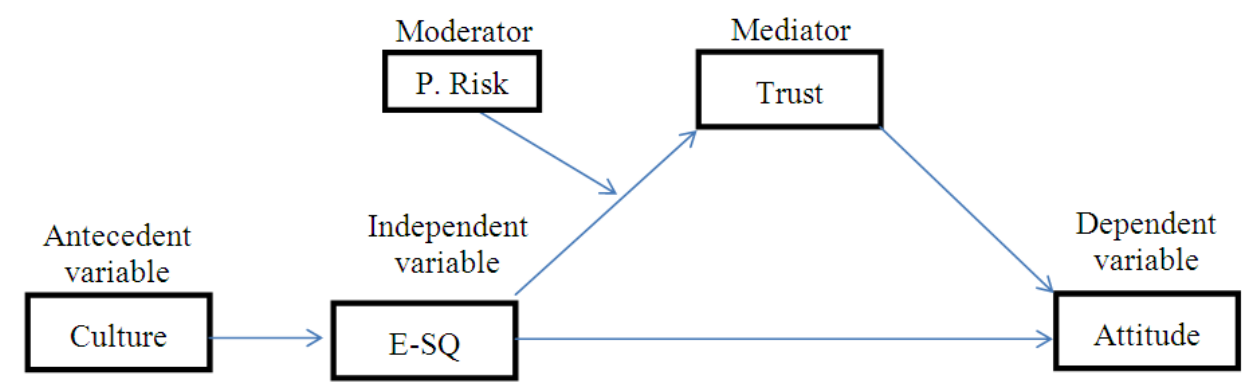

Fig. 2. Conceptual framework

\section{MATERIALS AND METHODS}

\subsubsection{Culture Measurement Instrument}

Kluckhohn and Kelly (1945) described culture as created designs in history for human living while Hofstede (1980) defined culture as the set of human mind programming that differentiates the members of one human group from the members of another. The culture metric proposed by Hofstede has a widespread popularity. Hofstede (1980) succeeded in identifying cultural dimensions following the involvement of 100,000 IBM employees hailing from 66 countries.

The present study collected contemporary data on cultural values of individuals. Culture dimension at the individual level was measured by Yoo et al. (2001). The use of scale that is newly developed runs the risk of producing date with invalid results, the reason for that because of its limited validation procedures. As a result, in the absence of better (validated) alternatives, CVSCALE selection for this study is judged acceptable.

They proposed the CVSCALE to measure the five cultural dimensions proposed by Hofstede at the individual level for a general context while gathering satisfactory psychometric properties. They argued that such measurement is imperative because the use of national-level measures of culture overlooks the cultural values variability among individuals in the country (Yoo and Donthu, 2002) and the differences in the cultural values between age groups in the same country. Hence, a need arises to identify the appropriate instruments to measure cultural values at the individual level. Table 1 shows the cultural dimensions and reliability of each dimension as stated by Yoo et al. (2011). The CVSCALE (Yoo and Donthu, 2002) was used to examine the cultural values of power distance, uncertainty avoidance, individualism/collectivism and masculinity/femininity. The other cultural dimension, known as Confucian dynamism, is long-term orientation. The majority of the 26 CVSCALE's items are modified versions of Hofstede's original scale items that reflect non-work related situations (Sobol, 2008).

The researcher chose CVSCALE as some researchers reported the lack of reliability and validity of Hofstede's scale (Bearden et al., 2006). On the other hand, the CVSCALE has good reliability, validity and crosscultural invariance (Patterson et al., 2006). Moreover, the items are advantageous over Hofstede's (2001) items as the instrument applies to general consumer situations, as opposed to limited situations. The cultural values at the individual level were operationalized by Yoo and Donthu's (2002) 26-item scale adapted from Hofstede's work-oriented items of national culture. The dimensions and items utilized in this study are presented in Table 2. 
Table 1. Culture measurements

\begin{tabular}{lllcc}
\hline Construct & Authors & Dimensions & Coefficient alpha & No. of items \\
\hline Culture & Yoo et al. (2011) & Power distance & 0.91 & 5 \\
& & Uncertainty avoidance & 0.88 & 5 \\
& & Collectivism & 0.85 & 6 \\
& Masculinity & 0.84 & 4 \\
\end{tabular}

Table 2. Culture measurements items

\begin{abstract}
Uncertainty
4 Standardized procedures in e-retailer website are helpful

5 Instructions in e-retailer website are important

\section{Collectivism}

12 Individuals should stick with the group even through difficulties

13 Group welfare is more important than individual rewards

14 Group success is more important than individual success

16 Group loyalty should be encouraged even if individual goals suffer

Masculinity

There are some jobs that a man can always do better than a woman

Long-Term Orientation

1 Careful management of money (thrift)

2 Going on resolutely in spite of opposition (persistence)

3 Personal steadiness and stability

4 Long term planning

5 Giving up today's fun for success in the future

6 Working hard for success in the future
\end{abstract}

1 It is important to have instructions in e-retailer website spelled out in detail so that I always know what I'm expected to do

2 It is important to closely follow instructions and procedures in e-retailer website

3 Rules and regulations in e-retailer website are important because they inform me of what is expected of me

6 People in higher positions should make most decisions without consulting people in lower positions

7 People in higher positions shouldn't ask the opinions of people in lower positions

8 People in higher positions should avoid social interaction with people in lower positions

9 People in lower positions should not disagree with decisions by people in higher positions

10 People in higher positions should not delegate important tasks to people in lower positions

11 Individuals should sacrifice self-interest for the group (either at school or the work place)

15 Individuals should only pursue their goals after considering the welfare of the group

17 It is more important for men to have a professional career than it is for women

18 Men usually solve problems with logical analysis. Women usually solve problems with intuition

19 Solving difficult problems usually requires an active, forceful approach, which is typical of men

These items were adopted in the present study in an attempt to measure culture at the individual level. Responses were scored along a seven-point Likert scale, where -3 indicated that respondents strongly disagreed with the statement and +3 indicated that they strongly agreed with the statement.

\subsubsection{Instrument Reliability and Validity}

The research instrument's reliability and validity are imperative when carrying out any research. According to Edwards and Talbot (1994), the validity information has its basis on the level to which the method chosen collect information the way it was originally expected. Validity refers to the degree to which a study is not controlled by any interference, ambiguity, control or variable manipulation (Sarantakos, 1997). The instrument's reliability is defined as the level to which the instrument produces the same outcome every time the trial is repeated (Carmines and Zeller, 1979).

The reliability and validity of the instruments are ensured through various ways. Among these ways is the development of suitable data collection and analysis 
methods. A pilot study entails the involvement of a small number of individuals and the aim behind it is to develop, adapt and ensure that the selected methods are feasible. In this research, the pilot study comprised 32 postgraduate students of Qassim University. The quality of the instruments and the questionnaire translation were ensured in light of the questions' precision, content and suitability. According to Fraenkel and Wallen (2000), the quality of the instrument utilized in any study is imperative as the data acquired through them are used to draw conclusions. When the researcher knows of any potential errors through a pilot study, a solution can be employed instead of wasting any resources by conducting data collection characterized by lack of reliability and validity.

A pilot study was conducted to confirm the reliability of the measurement. The result of the reliability analysis is depicted in Table 3. The table lists the Cronbach's alpha value for every dimension under study. The values of attitude, trust, risk, electronic service quality and culture came out to be $0.865,0.815,0.797,0.938$ and 0.782 , respectively, implying that all variables showed reliability and were suitable for further analysis. As stated above, validity test ensures that the instrument measures what it is meant to measure. In the present study, validity tests were conducted in the form of face validity. For face validity, the questionnaire was checked by an expert in the marketing field to confirm the items' ability to measure the variables.

The pilot study also revealed several insights to the researcher. During the pilot study, many insights into the web information-seeking attitude were obtained by the researcher. In addition, the reactions of the respondents towards the pilot study helped in many ways; for instance, students' reactions to it showed their misunderstanding of the terms "people in high level" and "people in low level". Hence, the clarification of concepts was made prior to distributing the final questionnaires to the respondents. Observations such as this one resulted in the final questionnaires' revision.

\section{RESULTS}

\subsection{Normality}

Normality is the most fundamental assumption in multivariate analysis (Hair et al., 2010). It measures whether differences revealed between the obtained and predicted scores of dependent variables (Stewart, 1981). The study sample was taken from the population, it is crucial to compare the sample normal distribution to one of the basic social science measurements, namely, the normal distribution of the population. The normal density function is described as a bell-shaped distribution that is symmetric to the values surrounding the mean.

In the present study, the entire variables were tested for normality where the values of skewness and kurtosis were examined to test the scores of normality. Table 4 showed that the overall the values of skewness and kurtosis were within the critical value. Hence, the possibility of issues surrounding nonnormal distribution appeared to be insignificant.

Table 3. Cronbach's Alpha Values for Each Dimension Result from Pilot Test

\begin{tabular}{llllll}
\hline Construct & Instrument & Dimensions & Original alpha & Alpha (pilot test) & No. of items \\
\hline Culture & Yoo et al. (2011) & Power distance & 0.91 & 0.534 & 5 \\
& & Uncertainty avoidance & 0.88 & 0.841 & 5 \\
& & Individualism & 0.85 & 0.828 & 6 \\
& & Long-term orientation & 0.79 & 0.888 & 6 \\
& Masculinity & 0.84 & 0.709 & 4 \\
\hline
\end{tabular}

Table 4. Normality test result

\begin{tabular}{llllll}
\hline & $\mathrm{N}$ & Mean & Std. deviation & Skewness & Kurtosis \\
\hline Attitude & 414 & 4.78 & 1.35 & -0.500 & -0.70 \\
Risk & 414 & 4.72 & 1.54 & -0.500 & -0.75 \\
Trust & 414 & 3.50 & 1.36 & 0.270 & -0.66 \\
E-sq & 414 & 3.52 & 1.43 & 0.500 & -0.60 \\
Culture & 414 & 3.47 & 1.09 & 0.005 & -0.24 \\
\hline
\end{tabular}




\subsection{Culture in Online Shopping}

In 1985, Mead defined culture as shared patterns of behavior. This definition includes at least two propositions. The first one is that culture is a grouplevel construct, located between the human nature and the personality of individuals that is usual to all of us. Professions, organizations and societies might be considered to have their own cultures. The second proposition suggests that cultural research includes little more than elaborating behavior and observing (Davison and Martinsons, 2003). Hofstede (1991) Hence, explained culture as "the collective programming of the mind which distinguishes the members of one group or category of people from another". Hofstede (1991) revealed that people in the same culture share a collective national character that shows their cultural mental programming. More specific, this mental programming shapes beliefs, values, expectations, assumptions, behavior and perceptions (Myers and Tan, 2002). Hofstede studies stressed that culture is same to the collective mental programming of a nation, minority, tribe, or a group.

Culture dimension at the individual level has been measured by Yoo et al. (2001). They proposed the CVSCALE to measure the five cultural dimensions proposed by Hofstede at the individual level for a general context while gathering satisfactory psychometric properties. The use of national-level measures of culture overlooks the cultural values variability among individuals in the country (Yoo and Donthu, 2002) and the differences in the cultural values between age groups in the same country. The CVSCALE (Yoo and Donthu, 2002) is used to examine the cultural values of power distance, uncertainty avoidance, individualism/collectivism, masculinity/femininity and Confucian dynamism or long-term orientation. Below is a short definition for each dimension:

- Power distance: The degree to which power in equality is distributed among the society's members

- Uncertainty avoidance: The degree to which organizational members perceive risks from uncertain situations or future uncertainty

- Individualism and collectivism: The explanation of the link between the individual and the collective whole that is revealed in the way people live within the society

- Masculinity and femininity: The level of roles division between men and women to which society places different stress on work goals and assertiveness versus personal goals and nurturance

- Long-term versus short-term orientation: The longterm orientation dimension can be interpreted as dealing with society's search for virtue

\subsection{Factor Analysis of Culture on Online Shopping}

Exploratory factor analysis was conducted on the 33 items of culture, which yielded a four-factor solution and explained $72 \%$ of the variance. In order to identify the orthogonal factor dimensions, both principal component and varimax procedures were utilized. For factor extraction, the latent root criterion of 1.0 was used while for inclusion, factor loadings of 0.40 were used as recommended by Hair et al. (1992).

The factor's composite reliability for each construct was investigated to examine the internal consistency of indicators, which measure the underlying factors (Fornell and Larcker, 1981). According to Netemeyer et al. (2003), a factor is reliable when its composite reliability is over 0.60 . The Cronbach's alpha for the four dimensions ranged from acceptable to very good. Specifically, the Cronbach's alphas for the first dimension, second dimension and third dimension were $0.949,0.895,0.916$ and 0.862 respectively, were seen to have a very good reliability. The reliability of these statements was regarded as being good and can therefore produce results that are consistent and are expected to be the same upon repetition. The Cronbach's alpha coefficients for each dimension of culture are illustrated in Table 5 .

\section{DISCUSSION}

\subsection{Culture Differences and Perceived e-Service Quality}

The objective was to investigate cultural background and its impact on e-service quality expectations among Malaysian and Saudis online consumers. The two countries were chosen because they are characterized as developing Asian countries having different cultural environments. 
Table 5. Factor analysis of culture

\begin{tabular}{|c|c|c|c|c|}
\hline Factor & $\begin{array}{l}\text { Factor } \\
\text { loading }\end{array}$ & Eigen & $\begin{array}{l}\text { Variance } \\
\text { explained }\end{array}$ & Alpha \\
\hline Dimension One & & 11.700 & 45.005 & 0.949 \\
\hline $\begin{array}{l}\text { It is important to closely follow instructions and } \\
\text { procedures in e-retailer website }\end{array}$ & 0.816 & & & \\
\hline $\begin{array}{l}\text { It is important to have instructions in e-retailer website spelled } \\
\text { out in detail so that I always know what I'm expected to do }\end{array}$ & 0.812 & & & \\
\hline $\begin{array}{l}\text { Rules and regulations in e-retailer website are important } \\
\text { because they inform me of what is expected of me }\end{array}$ & 0.806 & & & \\
\hline Instructions in e-retailer website are important & 0.797 & & & \\
\hline Standardized procedures in e-retailer website are helpful & 0.789 & & & \\
\hline $\begin{array}{l}\text { Individuals should only pursue their goals after } \\
\text { considering the welfare of the group }\end{array}$ & 0.587 & & & \\
\hline \multicolumn{5}{|l|}{$\begin{array}{l}\text { Solving difficult problems usually requires an active, } 0.536 \\
\text { forceful approach, which is typical of men }\end{array}$} \\
\hline \multicolumn{5}{|l|}{ Men usually solve problems with logical analysis. 0.524} \\
\hline \multicolumn{5}{|l|}{ Women usually solve problems with intuition } \\
\hline There are some jobs that a man can always do better than a woman. & 0.448 & & & \\
\hline Dimension Two & & 2.900 & 15.274 & 0.895 \\
\hline Long term planning & 0.838 & & & \\
\hline Giving up today's fun for success in the future & 0.829 & & & \\
\hline Personal steadiness and stability & 0.819 & & & \\
\hline Working hard for success in the future & 0.776 & & & \\
\hline Going on resolutely in spite of opposition (Persistence) & 0.723 & & & \\
\hline Careful Management of money (thrift) & 0.704 & & & \\
\hline $\begin{array}{l}\text { It is more important for men to have a professional } \\
\text { career than it is for women }\end{array}$ & 0.419 & & & \\
\hline \multirow{2}{*}{ Dimension Three } & & 7.297 & 0.916 & \\
\hline & 1.800 & & & \\
\hline $\begin{array}{l}\text { Individuals should sacrifice self-interest for the group } \\
\text { (either at school or the work place) }\end{array}$ & 0.824 & & & \\
\hline Group welfare is more important than individual rewards & 0.820 & & & \\
\hline Group success is more important than individual success & 0.817 & & & \\
\hline Group loyalty should be encouraged even if individual goals suffer & 0.756 & & & \\
\hline Individuals should stick with the group even through difficulties. & 0.681 & & & \\
\hline \multirow[t]{2}{*}{ Dimension Four } & & 4.486 & 0.862 & \\
\hline & 1.160 & & & \\
\hline $\begin{array}{l}\text { People in higher positions should not ask the opinions of people } \\
\text { in lower positions too frequently }\end{array}$ & 0.802 & & & \\
\hline $\begin{array}{l}\text { People in lower positions should not disagree with decisions } \\
\text { by people in higher positions }\end{array}$ & 0.795 & & & \\
\hline $\begin{array}{l}\text { People in higher positions should not delegate important } \\
\text { tasks to people in lower positions }\end{array}$ & 0.761 & & & \\
\hline $\begin{array}{l}\text { People in higher positions should avoid social interaction } \\
\text { with people in lower positions }\end{array}$ & 0.742 & & & \\
\hline $\begin{array}{l}\text { People in higher positions should make most decisions without } \\
\text { consulting people in lower positions }\end{array}$ & 0.714 & & & \\
\hline
\end{tabular}

In response to the first research objective concerning with the impact of cultural differences on the perception of e-service quality, two important points guided this objective:

- To develop a conceptual framework of service quality expectations that link culture to the development of expectations of e-service quality by the synthesis of literature dedicated to e-service quality expectations and cultural values

- To empirically evaluate the proposed framework in an environment characterized as being multicultural by comparing and contrasting between customers with different cultural values 
Results of this study showed that the Saudi sample gave more importance to e-service quality perception than the Malaysian sample. This result is in line with Hofstede (2001) who observed significant differences in cultural dimensions between Malaysia and Saudi Arabia. Consistently, Al-Ghaith et al. (2010) revealed that eservice quality was one of the important factors influencing e-service adoption and usage in Saudi Arabia The list included efficient delivery, e-commerce online presence, effective warranty agreements, a trial of tangible product experience and installation of high quality security systems with strong encryption algorithms for the prevention of hacking and fraud. These factors were discussed by the authors as part of eservice quality attributes.

Culture encapsulates elements like values and attitudes according to Hofstede (2001). It is crucial that the groups' background or values are taken into consideration when websites are designed. The understanding of the way cultural differences may affect the perceptions of consumers regarding e-service quality may enumerate ways on how to localize a global interface. On the other hand, consumer interfaces catering to all cultures may be similar to each other but there should be some features that enable the targeted customers to feel comfortable with it (Chau et al., 2002).

Despite the extensive examination of the impact of culture upon consumers' decision-making processes, the effect of cultural variables on consumers' use of perceptions to form expectations has not been given much attention by researchers especially in an online shopping context (Reid, 2011). Consumers use various cues and information sources to form their expectations of an upcoming service encounter (Coye, 2004) and this has significant implications to their eventual e-service quality evaluations and other outcomes (Kim and Moon, 2009).

\section{CONCLUSION}

Cultural issues of service quality perceptions were discussed. The theoretical framework of the present study was developed in this study three with the inclusion of five research propositions. This study is concluded by the present discussion that provided an overview of the study implications in light of theory and practice. The attitude toward online shopping model that emphasizes the relationships between eservice quality, culture, trust.
The aim of the study was to examine the factors that affect attitude of consumers towards Internet shopping in Malaysia and Saudi Arabia and how they affect purchase attitude. The findings revealed that service quality was relatively significant in its impact on consumer trust in online shopping, proving the proposed positive direct impact of perceived service quality upon customer trust. However, perceived risk was revealed to be linked with consumer trust towards online shopping. According to the results, trust in online retailer was positively associated with the attitude of consumers to online shopping. Therefore, marketers and managers should take into close consideration the requirements of trust development in online retailing. Finally, trust based on e-service quality is considered as the most suitable environment for developing favorable consumer attitude towards online shopping.

This study also contributed to the field of service quality expectations relationship with online shopping in the context of developing countries. It also examined the impact of culture on the service quality consumer expectations in both Malaysia and Saudi Arabia. In addition to comparing cultural values, the researcher confirmed the need for cultural adaptation through E-SQUAL. The findings indicated that in order to design strategies for effective service delivery and customer service expectation, the cultural background of consumers should be understood.

\section{REFERENCES}

Ajzen, I. and M. Fishbein, 1980. Understanding Attitudes and Predicting Social Behavior. 1st Edn., PrenticeHall, Englewood Cliffs, ISBN-10: 0139364439, pp: 278.

Al-Ghaith, W., L. Sanzogni and K. Sandhu, 2010. Factors influencing the adoption and usage of online services in Saudi Arabia. Electr. J. Inform. Syst. Dev. Count., 40: 1-32.

Bearden, W.O., M.R. Bruce and J.J. Nevins, 2006. A measure of long-term orientation: Development and validation. J. Acad. Market. Sci., 34: 456-467. DOI: 10.1177/0092070306286706

Blau, P.M., 1964. Exchange and Power in Social Life. 1st Edn., Wiley, New York, ISBN-10: 0471080306, pp: 352

Carmines, E. and R. Zeller, 1979. Reliability and Validity Assessment. 1st Edn., Sage Publications, Beverly Hills, ISBN-10: 0803913710, pp: 70 
Chau, P.C.M., M. Cole, P.A. Massey, M. MontoyaWeiss and R.M. O'Keefe, 2002. Cultural differences in the online behavior of consumers. Commun. ACM, 45: 138-143. DOI: 10.1145/570907.570911

Cho, J., 2004. Likelihood to abort an online transaction: Influences from cognitive evaluations, attitudes and behavioral variables. Inform. Manage., 41: 827-838. DOI: 10.1016/j.im.2003.08.013

Coye, R.W., 2004. Managing customer expectations in the service encounter. Int. J. Service Indus. Manage., 15: 54-71. DOI: $10.1108 / 09564230410523330$

Crotts, J. and R. Erdmann, 2000. Does national culture influence consumers' evaluation of travel services? A test of Hofstede's model of cross-cultural differences. Manage. Service Q., 10: 410-419. DOI: 10.1108/09604520010351167

Davis, F.D., R.P. Bagozzi and R.R. Warshaw, 1989. User acceptance of computer technology: A comparison of two theoretical models. Manage. Sci., 35: 982-1003. DOI: 10.1287/mnsc.35.8.982

Davison, R. and M. Martinsons, 2003. Guest editorial cultural issues and it management: Past and present. IEEE Trans. Eng. Manage., 50: 3-7. DOI: 10.1109/TEM.2003.808249

Edwards, A. and R. Talbot, 1994. The Hard-Pressed Researcher: A Research Handbook for the Caring Professions. 2nd Edn., Longman, Harlow, ISBN-10: 058236972X, pp: 222.

Fishbein, M. and I. Ajzen, 1975. Belief, Attitude, Intention and Behavior: An Introduction to Theory and Research. 1st Edn., Addison-Wesley Reading, Mass, ISBN-10: 0201020890, pp: 578.

Fornell, C. and D. Larcker, 1981. Evaluating structural equation models with unobservable variables and measurement error. J. Market. Res., 18: 39-50.

Fraenkel, J.R. and N.E. Wallen, 2000. How to Design And Evaluate Research In Education. 4th Edn., McGraw-Hill, Boston, ISBN-10: 007365728X, pp: 684.

Grabner-Krauter, S. and E.A. Kaluscha, 2003. Empirical research in on-line trust: A review and critical assessment. Int. J. Hum. Comput. Stud., 58: 783812. DOI: $10.1016 / \mathrm{S} 1071-5819(03) 00043-0$

Hair, J.F., R.E. Anderson, R.L. Tatham and W.C. Black, 1992. Multivariate Data Analysis With Readings. 3rd Edn., Macmillian, New York, ISBN-10: 002348750X, pp: 544.

Hair, J.F., W.C. Black, B.J. Babin and R.E. Anderson, 2010. Multivariate Data Analysis: A Global Perspective. 7th Edn., Pearson Education, New Jersey, ISBN-10: 0135153093, pp: 800.
Hofstede, G., 1980. Culture's Consequences: International Differences in Work-Related Values. 6th Edn., SAGE Publications, Beverly Hills, ISBN10: 080391444X, pp: 328.

Hofstede, G., 1991. Cultures and Organizations: Software of the Mind. 1st Edn., McGraw-Hill Ryerson, London, ISBN-10: 0077074742, pp: 279.

Hofstede, G., 2001. Culture's Consequences: Comparing Values, Behaviors, Institutions and Organizations Across Nations. 1st Edn., SAGE Publications, Thousand Oaks, ISBN-10: 0803973241, pp: 596.

Jarvenpaa, S.L., N. Tractinsky and L. Saarinen, 1999. Consumer trust in an internet store: A cross-cultural validation. J. Comput. Mediated Commun. DOI: 10.1111/j.1083-6101.1999.tb00337.x

Jarvenpaa, S.L., N. Tractinsky and M. Vitale, 2000. Consumer trust in an Internet store. Inform. Technol. Manage., 1: 45-71. DOI: 10.1023/A:1019104520776

Kim, W. G. and Y.J. Moon, 2009. Customers' cognitive, emotional and actionable response to the servicescape: A test of the moderating effect of the restaurant type. Int. J. Hospit. Manage., 28: 144-156. DOI: $10.1016 /$ j.ijhm.2008.06.010

Kluckhohn, C. and W.H. Kelly, 1945. The Concept of Culture. In: The Science of Man in the World Crisis, Linton, R. (Ed.), Columbia University Press, New York, pp: 78-106.

Kroeber, A.L. and C. Kluckhohn, 1978. Culture. 1st Edn., Kraus Reprint Company, Millwood, ISBN-10: 0527013242, pp: 223.

Leung, K., R.S. Bhagat, N.R. Buchan, M. Erez and C.B. Gibson, 2005. Culture and international business: Recent advances and their implications for future research. J. Int. Bus. Stud., 36: 357-378. DOI: 10.1057/palgrave.jibs. 8400150

Myers, M.D. and F. Tan, 2002. Beyond models of national culture in information systems research. J. Global Inform. Manage., 10: 24-32.

Netemeyer, R.G., W.O. Bearden and S. Sharma, 2003. Scaling Procedures: Issues and Applications. 1st Edn., SAGE Publications, Thousand Oaks, ISBN10: 0761920277, pp: 206

Park, C. and J.K. Jun, 2003. A cross-cultural comparison of Internet buying behavior: Effects of Internet usage, perceived risks and innovativeness. Int. Market. Rev., 20: 534-553. DOI: 10.1108/02651330310498771

Patterson, P.G., E. Cowley and K. Prasongsukarn, 2006. Service failure recovery: The moderating impact of individual-level cultural value orientation on perceptions of justice. Int. J. Res. Market., 23: 263277. DOI: 0.1016/j.ijresmar.2006.02.004 
Reid, V., 2011. A study of the influence of individuallevel cultural value orientation on the formation of service quality expectations. PhD Thesis, University of Nottingham.

Sarantakos, S., 1997. Social Research. 1st Edn., Macmillan Education Australia Pty Ltd, Melbourne.

Sekaran, U., 2003. Research Methods For Business: A Skill Building Approach. 1st Edn., Wiley India Pvt. Limited, ISBN-10: 8126509287, pp: 464.

Sobol, K., 2008. The global consumer culture: An empirical study in the Netherlands. MSc Thesis, Concordia University.

Stewart, D.W., 1981. The application and misapplication of factor analysis in marketing research. J. Market. Res., 18: 51-62.

Straub, D.W., D.L. Hoffman, B.W. Weber and C. Steinfied, 2002. Toward new metrics for net-enhanced organizations. Inform. Syst. Res., 13: 227-238.

Sultan, F., G.L. Urban, V. Shankar and I.Y. Bart, 2005. Determinants and role of trust in e-commerce: A large scale empirical study. J. Market., 69: 133-152.

Tractinsky, N. and S.L. Jarvenpaa, 1995. Information systems design decisions in a global versus domestic context. MIS Q., 16: 507-534.
Verhoef, P.C. and F. Langerak, 2001. Possible determinants of consumers' adoption of electronic grocery shopping in the Netherlands. J. Retail. Consumer Services, 8: 275-285. DOI: 10.1016/S0969-6989(00)00033-3

Vijayasarathy, L.R., 2002. Product characteristics and Internet shopping intentions. Internet Res., 12: 411426. DOI: $10.1108 / 10662240210447164$

Yoo, B. and N. Donthu, 2002. The effects of marketing education and individual cultural values on marketing ethics of students. J. Market. Educ., 24: 92-103. DOI: $10.1177 / 0273475302242002$

Yoo, B., N. Donthu and T. Lenartowicz, 2001. Individual cultural values: A multi-country investigation, school of business. Hofstra University, Hempstead.

Yoo, B., N. Donthu and T. Lenartowicz, 2011. Measuring Hofstede's five dimensions of cultural values at the individual level: Development and validation of CVSCALE. J. Int. Consumer Market., 23: 193-210. DOI: 10.1080/08961530.2011.578059 